\title{
GMR
}

\section{Characterizing and marker-assisting a novel chili pepper (Capsicum annuum L.) yellow bud mutant with cytoplasmic male sterility}

G.S. Sun ${ }^{1 *}$ Z.L. Dai ${ }^{1 *}$ P.W. Bosland ${ }^{2}$, Q. Wang $^{3}$ C.Q. Sun ${ }^{1}$, Z.C. Zhang and Z.H. $\mathrm{Ma}^{1,2}$

${ }^{1}$ Zhenjiang Institute of Agricultural Sciences in Hilly Area of Jiangsu Province, Jurong, Jiangsu, China

${ }^{2}$ Plant and Environmental Sciences, New Mexico State University, Las Cruces, NM, USA

${ }^{3}$ College of Horticulture, Jinling Institute of Technology, Nanjing, China

*These authors contributed equally to this study.

Corresponding author: Z.H. Ma

E-mail: sgs8725@163.com / mazhihu830@163.com

Genet. Mol. Res. 16 (1): gmr16019459

Received October 19, 2016

Accepted December 12, 2016

Published February 23, 2017

DOI http://dx.doi.org/10.4238/gmr16019459

Copyright $(2017$ The Authors. This is an open-access article distributed under the terms of the Creative Commons Attribution ShareAlike (CC BY-SA) 4.0 License.

ABSTRACT. Cytoplasmic male sterility (CMS) in pepper is a better way to produce hybrid seeds compared to manual production. We used the two sequence characterized amplified region (SCAR) markers (CRF-SCAR and CMS-SCAR ${ }_{130}$ ) in CMS pepper, to identify the genotype. We assembled two CMS yellow bud mutants (YBM; YBM12-A and YBM12-B). This mutation in leaf color is controlled by a single dominant nuclear gene. The aim was to create a new hybrid seed production method that reduces the costs and increases $F_{1}$ hybrid seed purity. The results suggest that the CRF-SCAR and $\mathrm{CMS} \mathrm{SCAR}_{130}$ markers can be used together in multiple generations to screen for restorer or maintainer genes. We found the marker linked to the restorer gene $(R f)$ in the $\mathrm{C}$-line and $\mathrm{F}_{1}$ hybrids, as well as

Genetics and Molecular Research 16 (1): gmr16019459 
partially in the $\mathrm{F}_{2}$ generation, whereas it was not found in the sterile YBM12-A or the maintainer line YBM12-B. In the $\mathrm{F}_{2}$ population, sterility and fertility segregated at a 3:1 ratio based on the CRF-SCAR marker. A $130 \mathrm{bp}$ fragment was produced in the YBM12-A, $\mathrm{F}_{1}$, and $\mathrm{F}_{2}$ populations, suggesting that these lines contained sterile cytoplasm. A $140 \mathrm{bp}$ fragment present in the YBM12-B and C-line indicated that these lines contained normal cytoplasm. In addition, we identified some morphological characters distinguishing sterile and fertile buds and flowers that may be linked to the sterility gene. If more restorer lines are identified, CMS expressing the YBM trait can be used in hybrid seed production.

Key words: Capsicum annuum L.; CRF-SCAR; CMS-SCAR ${ }_{130}$; Floral organ; Cytoplasmic male sterility (CMS); Yellow bud mutant

\section{INTRODUCTION}

Male sterility plays an important role in plant breeding. It can be used to produce hybrid seeds and as a plant breeding tool for improving populations, backcrossing, inter specific hybridization, and other intermediate breeding procedures (Budar et al., 2003). Fertility gene restorers in the nucleus suppress cytoplasmic male sterility (CMS) phenotypes, and nuclear restoration allows the CMS system to be exploited for increased yield of commercial heterotic seeds. This eliminates the intensive labor and expensive manual processes involved in emasculation (Gulyas et al., 2006). The association of CMS with abnormal mitochondrial gene expression has been established in many plant species, including sugar beet (Powling, 1982), maize (Dewey et al., 1986), petunia (Kool et al., 1983; Young and Hanson, 1987; Nivison and Hanson, 1989), sunflower (Horn et al., 1991; Köhler et al., 1991; Laver et al., 1991; Monéger et al., 1994), common bean (Johns et al., 1992), and carrot (Pingitore et al., 1989).

There are two types of male sterility in pepper (Capsicum annuum L.). These are genetic male sterility and CMS (Martin and Crawford, 1951; Peterson, 1958). When pepper male sterility was first reported, multiple alleles of the restoring gene $(R f)$ were found (Peterson, 1958). Male sterile plants are common in nature where the interaction between genotype and environment determines plant fertility (Peterson, 1958; Huang et al., 2015). CMS causes mitochondrial-nuclear interactions with restorer genes in the nucleus, which can restore normal pollen production in CMS plants. CMS plants can be used to produce $\mathrm{F}_{1}$-hybrid seeds commercially (Dhaliwal and Jindal, 2014).

Recently published chili genes suggested that pepper genetic trait performance was based on implicit relationships between traits (Wang and Bosland, 2006). The new list contains 292 genes. If plants contain lut-1 to lut-18 lutescens then the cotyledons and leaves turn uniformly yellow or a lighter green than normal (Csillery, 1980, 1983, 1985). However, distinct accessions may show different intensities of color among lut-1 to lut-18 containing plants (Csillery, 1985). The yellow bud mutant (YBM) pepper was identified as a proposed lut19 lutescens C. annuum mutant in 2006, whose cotyledons and leaves are uniformly yellowgreen (Figure 1) (Ma et al., 2001; Wang and Bosland, 2006).

Genetics and Molecular Research 16 (1): gmr16019459 


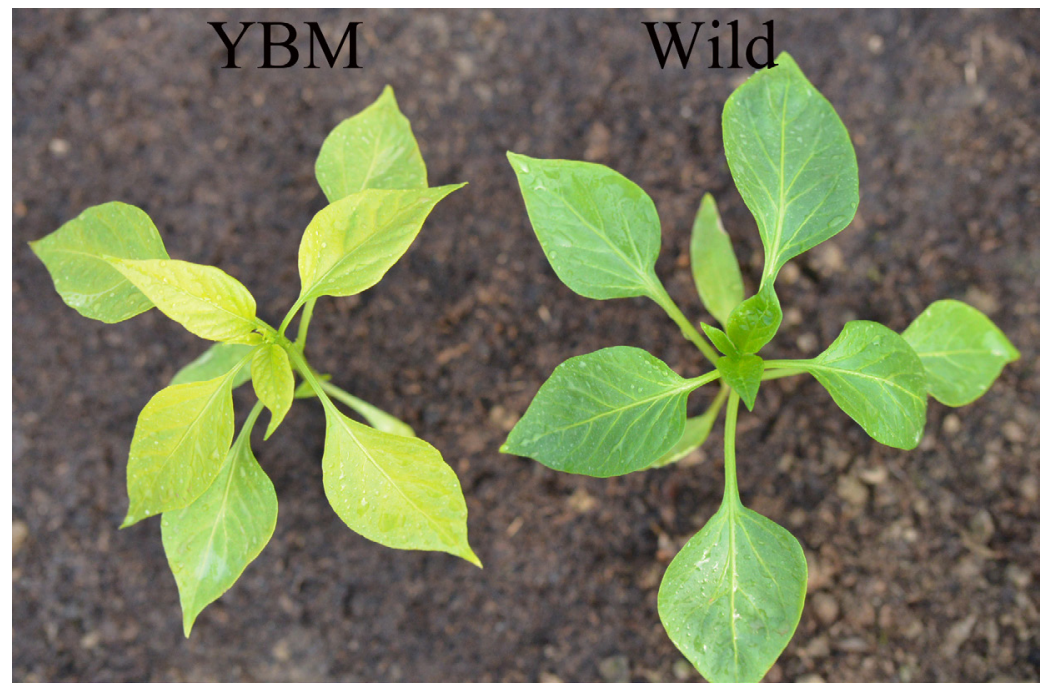

Figure 1. Yellow bud mutant and wild type Capsicum annuиm L.

Most yellow or yellow-green leaf color marker genes lead to bleaching, and the plants are short, lack vigor, and die. The yellow bud mutation (Ma et al., 2016) is often controlled by a single recessive nuclear gene, but a few are controlled by two pairs of nuclear genes (Xiao et al., 1995). A genetic analysis by Ma et al. (2001) showed that there were lut-19 segregating $\mathrm{F}_{2}$ progenies and corresponding $\mathrm{F}_{3}$ families. This indicated that the phenotype was controlled by a single recessive nuclear gene, which means that it can be used as a morphological marker in genetic crop breeding and to test the purity of $\mathrm{F}_{1}$ hybrid seeds or parent seeds. Ma et al. (2005) selected and bred a YBM-CMS line using the lut-19 gene.

Molecular marker-assisted selection is widely utilized in crop breeding, especially for showing recessive or polygenic inheritance traits that are difficult to select directly (Chen et al., 2010). Sterility expression (gene expression) is influenced by the environment, but the environment does not alter the gene (Shifriss and Guri, 1979; Dhaliwal and Jindal, 2014). Some CMS molecular markers have been used for fertility selection in pepper. Kim and Kim (2005) developed sequence characterized amplified region (SCAR) markers for the early identification of the CMS genotype in chili pepper. Two CMS-specific SCAR markers (coxII and atp6) were developed to distinguish normal (N) from sterile (S) cytoplasm using polymerase chain reaction (PCR) analysis. Other molecular markers, such as accD-U7 (Jo et al., 2009) and orf456 (Kim et al., 2007), have been used to speed up CMS selection and application, and to improve breeding outcomes. However, a single molecular marker for determining S-cytoplasm has not yet been identified as reliable or correct. Recently, Ji et al. (2014) developed a new molecular marker, CMS-SCAR ${ }_{130}$, that could reliably distinguish S-cytoplasm in pepper CMS lines (130 bp) from the maintainer line (140 bp). The results indicated that CMS-SCAR ${ }_{130}$ is more reliable than the orf507, $\Psi$ atp6-2, or accD-U markers. If the CMS-SCAR ${ }_{130}$ and CRF-SCAR markers both work in the YBM-CMS lines, we can easily identify the best suited restorer lines, which is a key step to reduce the workload for the restorer line. 


\section{MATERIAL AND METHODS}

\section{Plant materials}

We used the YBM-CMS lines YBM12-A (S/rfrf), maintainer line YBM12-B (N/rfrf), and restorer line $\mathrm{C}(\mathrm{N} / R f R f)$ (Ma et al., 2005), which in chili pepper are all known to contain $\mathrm{CMS}$ and normal cytoplasm. The $\mathrm{F}_{1}(\mathrm{YBM} 12-\mathrm{A} \times \mathrm{C})$ and $\mathrm{F}_{2}(\mathrm{YBM} 12-\mathrm{A} \times \mathrm{C} \otimes)$ hybrids were also used. In the blooming stage of anthesis, five flowers were randomly selected to evaluate the fertility of YBM12-A, YBM12-B, C, and the YBM12-A x C $\mathrm{F}_{1}$ hybrids according to the method of Gulyas et al. (2006). Morphological differences were investigated between YBM12-A and the maintainer line YBM12-B buds. The purity of $F_{1}$ hybrid seeds was tested when they had 1-2 true leaves. Ten plants of each parent (YBM12-A, C, and YBM12-B), $100 \mathrm{~F}_{1}$ plants, and 125 plants from the segregating $\mathrm{F}_{2}$ generation were characterized in the experiment.

All materials were provided by the Zhenjiang Agricultural Research Institute (Table 1). All plants were grown under standard greenhouse conditions at $25^{\circ}-28^{\circ} \mathrm{C}, 45$ $60 \%$ relative humidity, and a $16 \mathrm{~h}$ light $/ 8 \mathrm{~h}$ dark cycle.

\section{Table 1. Cytoplasmic male sterility lines used in the study.}

\begin{tabular}{l|c|c|c|c}
\hline$F_{1}$ hybrids & Genotype & Phenotype & Line function & Leaf color \\
\hline YBM12-A & $\mathrm{S}(r f r f)$ & Sterile & A-line & Yellow \\
\hline YBM12-B & $\mathrm{N}(r f r f)$ & Fertile & B-line & Yellow \\
\hline $\mathrm{C}$ & $\mathrm{N}(R f R f)$ & Fertile & C-line & Green \\
\hline $\mathrm{F}_{1}:$ YBM12-A $\mathrm{C} C$ & $\mathrm{~S}(R f r f)$ & Fertile & $\mathrm{F}_{1}$ hybrids & Green \\
\hline $\mathrm{F}_{2}:$ YBM12-A $\mathrm{C} \mathrm{C} \otimes$ & $\mathrm{S}(R f R f, R f r f) / \mathrm{S}(r f r f)$ & Fertile/Sterile $=3 / 1$ & $\mathrm{~F}_{2}$ generation & Green/Yellow $=3 / 1$
\end{tabular}

Ten plants of each of YBM12-A, YBM12-B, and C; 100 plants of $F_{1}$, and 125 plants for segregating $\mathrm{F}_{2}$ generation were characterized.

\section{Floral organ analysis}

Morphological differences in the shape and size of anthers and petals were measured in YBM12-A, YBM12-B, and $\mathrm{C}$, as well as in the $\mathrm{F}_{1}$ and $\mathrm{F}_{2}$ hybrids. Morphological differences in the buds of the $\mathrm{F}_{2}$ generation fertile and sterile plants at 1-2 days before flowering and at flowering were also noted.

\section{CRF-SCAR and CMS-SCAR ${ }_{130}$ marker analysis}

The fertility of YBM12-A, YBM12-B, C, and the $\mathrm{F}_{1}$ and $\mathrm{F}_{2}$ hybrids were identified using CMS-SCAR ${ }_{130}$ and CRF-SCAR molecular markers. Early seedling leaves from which DNA was extracted were used. They were identified as being sterile or fertile based on the flower stage at the Fabian Garcia Science Center, NMSU, Las Cruces, NM, USA.

Total DNA was extracted from fresh leaves of each plant using a DNAiso reagent kit (Takara, Tokyo, Japan). The primers were designed according to Lee et al. (2004), Gulyas et al. (2006), and Ji et al. (2014). The CRF-SCAR (Table 2) PCR amplification was carried out with an initial denaturation step at $95^{\circ} \mathrm{C}$ for $3 \mathrm{~min}, 36$ cycles of amplification with each cycle consisting of $94^{\circ} \mathrm{C}$ for $30 \mathrm{~s}$, annealing at $50^{\circ} \mathrm{C}$ for $30 \mathrm{~s}, 68^{\circ} \mathrm{C}$ for $50 \mathrm{~s}$, and a final extension 
at $68^{\circ} \mathrm{C}$ for $3 \mathrm{~min}$. The reaction component volume $(15 \mu \mathrm{L})$ for the PCR, included $1.5 \mu \mathrm{L}$ template DNA, 1.5 $\mu \mathrm{L}$ CRF-SCAR-Forward primer, $1.5 \mu \mathrm{L}$ CRF-SCAR-Reverse primer, 7.5 $\mu \mathrm{L}$ of premix taq (RR901, Takara, Tokyo, Japan)Premer, and $3 \mu \mathrm{L}$ water. The PCR products were visualized on $1 \%$ agarose gels stained with ethidium bromide and photographed under ultraviolet light.

Table 2. Marker primers used in this study.
\begin{tabular}{l|l|l|l}
\hline \multirow{2}{*}{ Marker name } & \multicolumn{2}{|c}{ Primer (5'-3') } & Reference \\
\cline { 2 - 4 } & Forward & Reverse & \\
\hline CRF-SCAR & GTACACACCACTCGTCGCTCCT & TTCTTGGGTCCCTTTCCAA & Lee et al. (2004); Gulyas et al. (2006) \\
\hline CMS-SCAR 130 & TTACGGCTCGTTACCGCAGCG & CAATTGACCGACCCGCCAT & Ji et al. (2014) \\
\hline
\end{tabular}

The CMS-SCAR ${ }_{130}$ (Table 2) PCR amplification started with an initial denaturation step of $95^{\circ} \mathrm{C}$ for $3 \mathrm{~min}$, followed by 37 amplification cycles amplification with each cycle consisting of $94^{\circ} \mathrm{C}$ for $30 \mathrm{~s}$, annealing at $57^{\circ} \mathrm{C}$ for $30 \mathrm{~s}, 68^{\circ} \mathrm{C}$ for $15 \mathrm{~s}$, and a final extension at $68^{\circ} \mathrm{C}$ for $5 \mathrm{~min}$. The reaction component volume $(15 \mu \mathrm{L})$ for the PCR included $1.5 \mu \mathrm{L}$ template

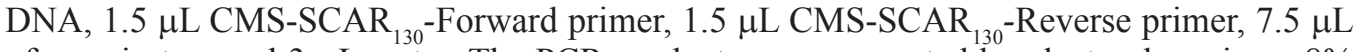
of premix taq, and $3 \mu \mathrm{L}$ water. The PCR products were separated by electrophoresis on $8 \%$ polyacrylamide gels and visualized by silver staining.

\section{RESULTS}

\section{Floral organ performance in sterile and fertile chili pepper plants}

To determine whether sterility could impact the floral organs, the morphology of the $\mathrm{F}_{2}$ population floral organs (pollen, fruit, and flower shape) in the greenhouse was considered. The results showed that it was consistent with the molecular marker results. Figure 2 demonstrates that YBM12-A and the $\mathrm{F}_{2}$ sterile plants could be distinguished from YBM12-B, C, $F_{1}$, and $F_{2}$ fertile plants based on external floral organ characters. We hypothesized that sterility would be associated with the floral organ performance and found that, at 1-2 days before flowering, sterile plant buds were smaller in general and more elongated than normal. The petals had shriveled and did not open to the same extent as the fertile flowers. We also investigated the shape of the stamens in sterile and fertile flowers. As predicted, in sterile flowers stamen abortion and shortening occurred and the anthers were small, black, and triangular in shape but contained no pollen (Figures 3 and 4). These results were consistent with the results for fruit quantity and the spontaneous fruit-setting rate recorded in the field, which indicated that chili pepper $\mathrm{F}_{1}$ hybrid fertility was restored by a single dominant nuclear gene (Peterson, 1958; Novak et al., 1971; Shifriss and Guri, 1979; Gulyas et al., 2006).

\section{Analysis of the $R f$-linked DNA marker (CRF-SCAR)}

To test $R f$-linkage, we investigated polymorphism in the $R f$-linked DNA marker CRF-SCAR in the parental lines YBM12-A, YBM12-B, and C, was well as in the $\mathrm{F}_{1}$ and $\mathrm{F}_{2}$ hybrids. As expected, the marker was present in $\mathrm{C}$ and $\mathrm{F}_{1}$ lines, and showed partially restored fertility in the $\mathrm{F}_{2}$ generation. However, it was not found in the YBM12-A or the maintainer line YBM12-B (Figure 5).

Genetics and Molecular Research 16 (1): gmr16019459 


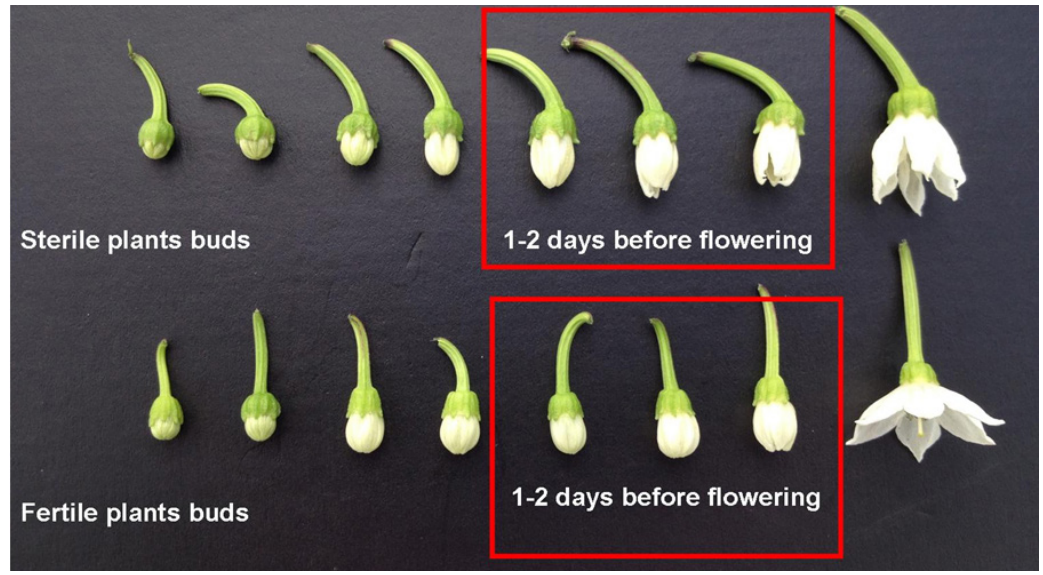

Figure 2. Bud characteristics of fertile and sterile plants in the segregating $\mathrm{F}_{2}$ generation.

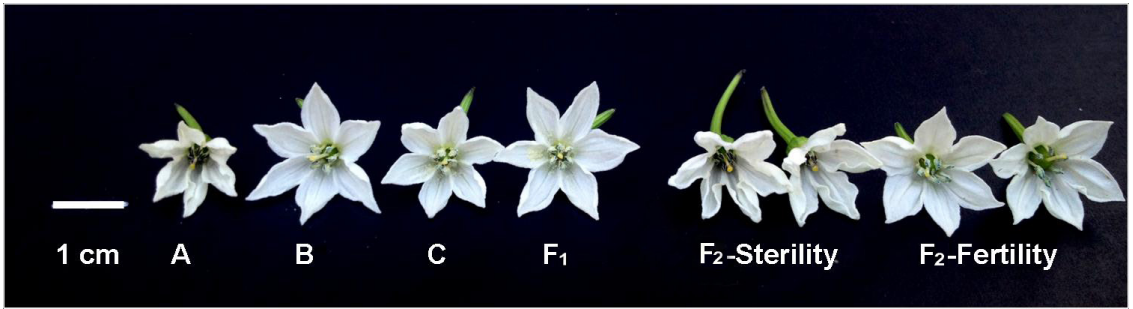

Figure 3. Flower characteristics of the parents, and the $\mathrm{F}_{1}$ and $\mathrm{F}_{2}$ hybrid generations.

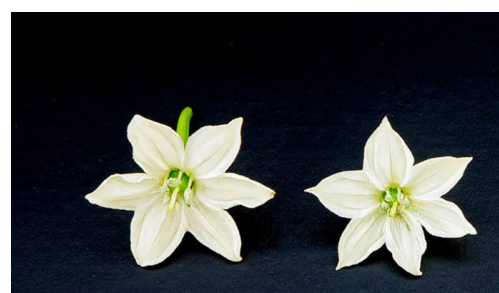

$F_{2}$ Fertility

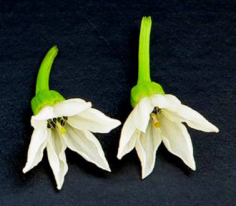

$F_{2}$ Sterility

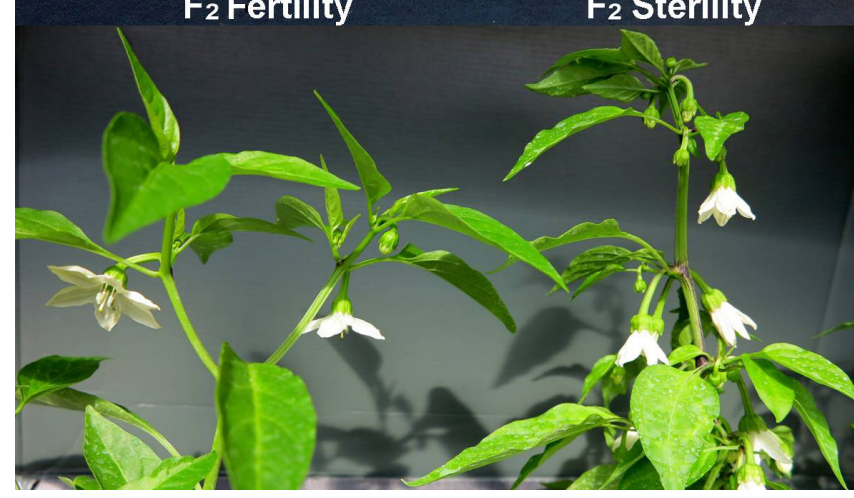

Figure 4. $\mathrm{F}_{2}$ generation fertile and sterile flowers in the field.

Genetics and Molecular Research 16 (1): gmr16019459 


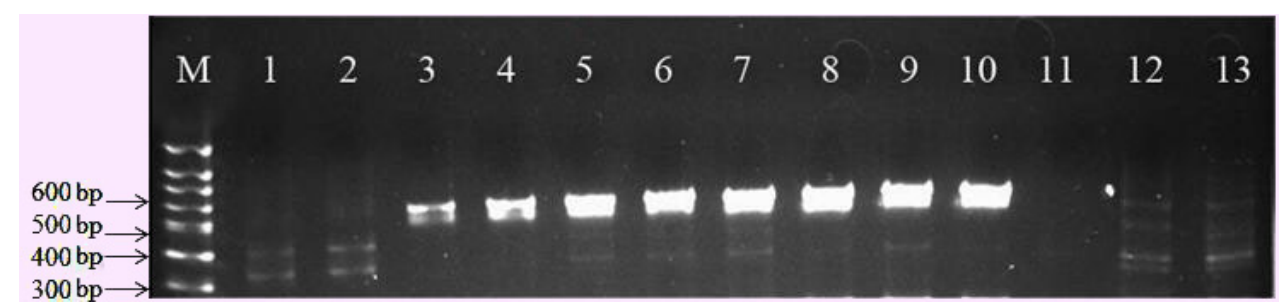

Figure 5. $R f$-linked CRF-SCAR marker in the parents, and the $\mathrm{F}_{1}$ and $\mathrm{F}_{2}$ hybrid generations. Lane $M$ : 100 bp ladder marker, lane 1: YBM12-A, lane 2: YBM12-B, lane 3: C-line, lane 4: $\mathrm{F}_{1}(\mathrm{YBM} 12-\mathrm{A} \times \mathrm{C})$, lanes 5-10: $\mathrm{F}_{2}(\mathrm{YBM} 12-\mathrm{A}$ $\mathrm{x} \mathrm{C} \otimes)$ /fertility, lanes 11-13: $\mathrm{F}_{1}(\mathrm{YBM} 12-\mathrm{A} \mathrm{x} \mathrm{C} \otimes)$ /sterility.

To determine the separation of fertility in the $\mathrm{F}_{2}$ generation, a total of 125 individuals were examined (Table 3), 93 plants contained the $R f$-linked DNA marker and 32 plants did not. The $R f$ marker segregated in a 3:1 ratio, $\chi^{2}(0.024$, d. $\mathrm{f}=1)<\chi_{0.05,1}^{2}=3.84$. This indicates that the $F_{1}$ hybrids produced by cross-combinations were fertile, and that chili pepper $F_{1}$ hybrid fertility was restored by a single dominant nuclear gene.

Table 3. Male sterility and fertility rates in the $\mathrm{F}_{2}$ population.

\begin{tabular}{|c|c|c|c|c|}
\hline Genotype & Result & $R f R f / R f r f$ & Rfrf & Total \\
\hline \multirow[t]{3}{*}{$\mathrm{F}_{1}(\mathrm{YBM} 12-\mathrm{A} \times \mathrm{C})$} & Observed & 110 & 0 & 110 \\
\hline & Expected & 110 & 0 & 110 \\
\hline & $\chi^{2}$ & \multicolumn{3}{|c|}{0} \\
\hline \multirow{4}{*}{$\mathrm{F}_{2}(\mathrm{YBM} 12-\mathrm{A} \times \mathrm{C} \otimes)$} & Observed $R f$ marker & 93 & 32 & 125 \\
\hline & Observed pollen content & 93 & 32 & 125 \\
\hline & Expected & $93.75(3 / 4)$ & $31.25(1 / 4)$ & 125 \\
\hline & $\chi^{2}$ & \multicolumn{3}{|c|}{$\chi^{2}=0.024$} \\
\hline
\end{tabular}

A total of $100 \mathrm{~F}_{1}$ plants and 125 plants for the segregating $\mathrm{F}_{2}$ generation were characterized.

\section{Analysis of the S-linked DNA marker (CMS-SCAR $\left.{ }_{130}\right)$}

YBM12-A, YBM12-B, restorer line $\mathrm{C}$, and the $\mathrm{F}_{1}$ and $\mathrm{F}_{2}$ hybrids are polymorphic for the S-linked DNA marker (Ji et al., 2014). Ji et al. (2014) developed the CMS-SCAR ${ }_{130}$ marker by deleting $10 \mathrm{bp}$ at a sequence-related amplified polymorphism primer binding site in the CMS line (130 bp) compared to the maintainer line (140 bp). To test CMS-SCAR ${ }_{130}$ markerlinkage, we investigated polymorphism in the CMS-SCAR ${ }_{130}$ marker in the CMS YBM12-A, YBM12-B, and $\mathrm{C}$, as well as in the $\mathrm{F}_{1}$, and $\mathrm{F}_{2}$ population individuals. The results showed that the $130 \mathrm{bp}$ marker was present in YBM12-A and in the $\mathrm{F}_{1}$ and $\mathrm{F}_{2}$ progeny, whereas the $140 \mathrm{bp}$ fragment was detected in the maintainer line YBM12-B and restorer line $\mathrm{C}$ (Figure 6).

\section{DISCUSSION}

The yellow-green seedling marker is a good phenotypic marker for identifying the single recessive nuclear gene controlling the lutescens phenotype. The $\mathrm{F}_{2}$ fertile plants used in this study had flower petals and stigmas that were almost vertical, whereas the $F_{2}$ sterile plant petals and stigmas only opened to an angle of 15-30 degrees (Figure 4). The floral organ analysis was consistent with the study by Yuan et al. (2003), which showed that an ecotypical 


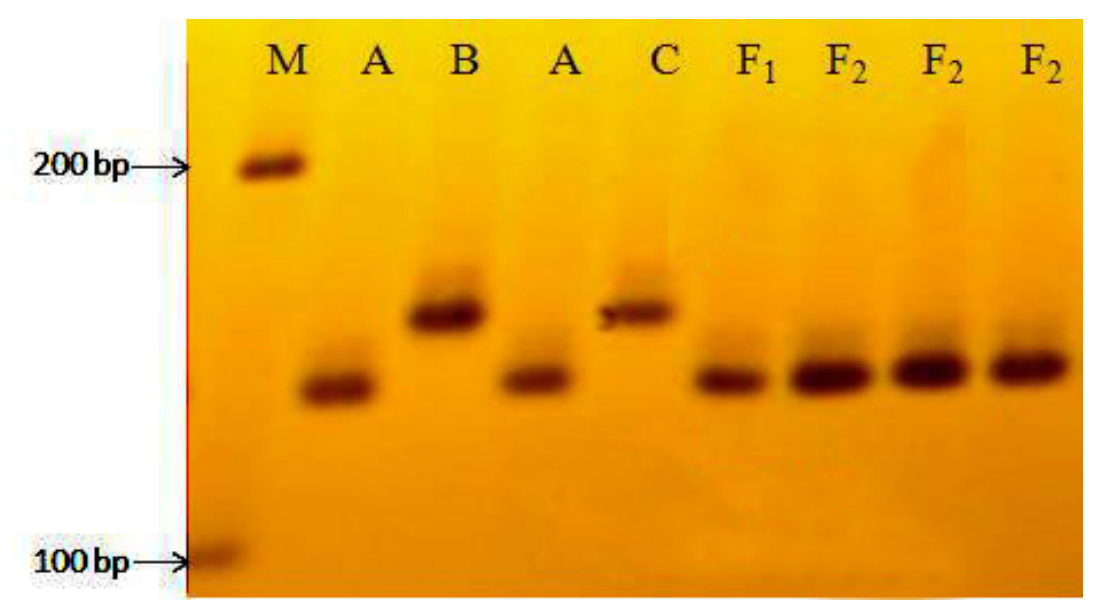

Figure 6. $P C R$ amplification of the S-linked CMS-SCAR ${ }_{130}$ DNA marker in the parents and their $F_{1}$ and $F_{2}$ hybrid generations.

CMS line from Brassica napus L. led to fertile plants whose floral organ performance was normal because the petals were flat and opened correctly. Our results indicated that sterile and fertile plants can be very easily identified in the field, by analyzing their floral organs. It is unlikely that the sterile plant flower organ traits in YBM12-A are linked to the sterility gene. In hybrid seed production, seed purity cannot reach $100 \%$, even using the CMS line. Many reports have indicated that CMS lines are sensitive to low temperatures (Peterson, 1958; Shifriss, 1997; Dhaliwal and Jindal, 2014) with selfing occurring at low temperatures. However, the $\mathrm{F}_{1}$ produced by the YBM-CMS can be used to efficiently remove pseudo-hybrids before engraftment. In addition, there is no undesirable effect on the agronomic performance in the YBM-CMS line.

Although varying results about the inheritance of fertility restoration have been reported, they have all shown that fertility in pepper was caused by a single dominant gene located in the nucleus (Peterson, 1958; Novak et al., 1971; Shifriss and Guri, 1979; Gulyas et al., 2006). The CRF-SCAR marker results in our study showed that the fertile and sterile plants segregated in a 3:1 ratio (Table 3), which suggests that the $R f$ gene in our CMS material was a major $R f$ gene (Peterson, 1958; Novak et al., 1971). Several CMS markers have been reported (Kim and Kim, 2005; Jo et al., 2009), but the CMS-SCAR ${ }_{130}$ marker (Ji et al., 2014) has been suggested to be more reliable than others (Dhaliwal and Jindal, 2014). In our work, the $130 \mathrm{bp} \mathrm{CMS-SCAR}{ }_{130}$ DNA marker differentiated fertile individuals in line YBM12-A, and in the $F_{1}$ and $F_{2}$ hybrids. Fragments of 140 bp were only found in the YBM12-B and C-line (Figure 6). This study has verified that the $\mathrm{C}$-line used in this study is the same as other $\mathrm{C}$-lines that contain N-cytoplasm (Ji et al., 2014), and that our C-line also contains N-cytoplasm. The $\mathrm{CMS}_{\mathrm{SCAR}}{ }_{130}$ DNA marker accurately distinguished S-cytoplasm from N-cytoplasm, which means that it can be used to screen for maintainer lines. The CRF-SCAR marker was present in the C-line, but not in the YBM12-A or YBM12-B, and was only partially expressed in the $\mathrm{F}_{2}$ population.

The observed morphological performance (flower, pollen, and fruit set) was consistent with the marker results, which indicated that both markers could be used to accurately identify

Genetics and Molecular Research 16 (1): gmr16019459 
the maintainer and restorer lines in chili pepper sterile lines in the future. As such, these markers provide an alternative to intensive manual labor in the field. Ma et al. (2013) showed that different restorers might carry different $R f$ genes. We therefore doubt that the restorer lines selected by the two markers will be limited and decreased. Lee et al. (2008) identified another partial restoration locus related to fertility in CMS, which was either tightly linked with three $R f$-linked markers or was a third allele of the $R f$ locus. We only identified the $R f$ linkage using the CRF-SCAR marker; the presence of minor and modifier genes can therefore not be eliminated in our material. Anon (2006) pointed out that the S-cytoplasm might have undesirable effects on the agronomic performance of both the CRF-SCAR and CMS-SCAR ${ }_{130}$ DNA markers used in pepper; however, this problem can be eliminated.

In future work, we can use these two markers to screen for suitable restorer lines, which have the N-cytoplasm and $R f$ gene. The traditional hybrid pepper seed production will thus change from hand-emasculation to CMS systems, which will revolutionize the seed production industry. In addition, the $\mathrm{YBM}$ is beneficial to increase the purity of $\mathrm{F}_{1}$ seeds, and, as such, the YBM trait can go from being something negative to something positive.

\section{Conflicts of interest}

The authors declare no conflict of interest.

\section{ACKNOWLEDGMENTS}

Research supported by the Jiangsu province "six talent peaks" high level talents project of Jiangsu province, China (\#NY-042), and the Youth Natural Science Foundation of Jiangsu province, China (\#BK20130093).

\section{REFERENCES}

Anon (2006). Cytoplasmic-genic male sterile pepper. Annual Report 2005-06. AVRDC-The World Vegetable Center, Shanhua, Taiwan, 18-21.

Budar F, Touzet P and De Paepe R (2003). The nucleo-mitochondrial conflict in cytoplasmic male sterilities revisited. Genetica 117: 3-16. http://dx.doi.org/10.1023/A:1022381016145

Chen F, Zhu SW, Xiang Y, Jiang HY, et al. (2010). Molecular marker-assisted selection of the ae alleles in maize. Genet. Mol. Res. 9: 1074-1084. http://dx.doi.org/10.4238/vol9-2gmr799

Csillery G (1980). Gene mapping of the pepper needs more initiatives (contribution to the gene list). Proc. 4th Eucarpia meeting of Capsicum working group, 17-19 May 1980, Wageningen, the Netherlands. 5-9.

Csillery G (1983). New Capsicum mutants found on seeding, growth type, leaf, flower and fruit. Proc. 5th Eucarpia meeting of Capsicum and eggplant working group, 4-7 July 1983, Ploviv. 127-130.

Csillery G (1985). Abnormal segregation ratio in a 'lutescens' hybrid in Capsicum bacatum. Capsicum Eggplant Nwsl. 4: 43.

Dewey RE, Levings CS, 3rd and Timothy DH (1986). Novel recombinations in the maize mitochondrial genome produce a unique transcriptional unit in the Texas male-sterile cytoplasm. Cell 44: 439-449. http://dx.doi.org/10.1016/0092$\underline{8674(86) 90465-4}$

Dhaliwal MS and Jindal SK (2014). Induction and exploitation of nuclear and cytoplasmic male sterility in pepper (Capsicum spp.): a review. J. Hortic. Sci. Biotechnol. 89: 471-479. http://dx.doi.org/10.1080/14620316.2014.11513108

Gulyas G, Pakozdi K, Lee JS and Hirata Y (2006). Analysis of fertility restoration by using cytoplasmic male-sterile red pepper (Capsicum annuum L.) lines. Breed. Sci. 56: 331-334. http://dx.doi.org/10.1270/jsbbs.56.331

Horn R, Köhler RH and Zetsche K (1991). A mitochondrial $16 \mathrm{kDa}$ protein is associated with cytoplasmic male sterility in sunflower. Plant Mol. Biol. 17: 29-36. http://dx.doi.org/10.1007/BF00036803

Genetics and Molecular Research 16 (1): gmr16019459 
Huang W, Ji JJ, Li C, Li GQ, et al. (2015). Novel genetic male sterility developed in (Capsicum annuum x C. chinense) $\mathrm{x}$ C. pubescens and induced by $\mathrm{HNO} 2$ showing Mendelian inheritance and aborted at telophase of microspore mother cell stage. Genet. Mol. Res. 14: 3318-3329. http://dx.doi.org/10.4238/2015.April.13.11

Ji JJ, Huang W, Yin YX, Li Z, et al. (2014). Development of a SCAR marker for early identification of S-cytoplasm based on mitochondrial SRAP analysis in pepper (Capsicum annuum L.). Mol. Breed. 33: 679-690. http://dx.doi. org/10.1007/s11032-013-9984-z

Jo YD, Jeong HJ and Kang BC (2009). Development of a CMS-specific marker based on chloroplast-derived mitochondrival sequence in pepper. Plant Biotechnol. Rep. 3: 309-315. http://dx.doi.org/10.1007/s11816-009-0103-x

Johns C, Lu M, Lyznik A and Mackenzie S (1992). A mitochondrial DNA sequence is associated with abnormal pollen development in cytoplasmic male sterile bean plants. Plant Cell 4: 435-449. http://dx.doi.org/10.1105/tpc.4.4.435

Kim DH and Kim BD (2005). Development of SCAR markers for early identification of cytoplasmic male sterility genotype in chili pepper (Capsicum annuum L.). Mol. Cells 20: 416-422.

Kim DH, Kang JG and Kim BD (2007). Isolation and characterization of the cytoplasmic male sterility-associated orf456 gene of chili pepper (Capsicum annuum L.). Plant Mol. Biol. 63: 519-532. http://dx.doi.org/10.1007/s11103-0069106-y

Köhler RH, Horn R, Lössl A and Zetsche K (1991). Cytoplasmic male sterility in sunflower is correlated with the co-transcription of a new open reading frame with the atpA gene. Mol. Gen. Genet. 227: 369-376. http://dx.doi. org/10.1007/BF00273925

Kool AJ, Bot PVM and Marrewijk GAM (1983). Analysis of cytoplasmic variations associated with cytoplasmic male sterility in Petunia hybrida plants. 10 $0^{\text {th }}$ Eucarpia Congress, Wageningen, abstract 115.

Laver HK, Reynolds SJ, Moneger F and Leaver CJ (1991). Mitochondrial genome organization and expression associated with cytoplasmic male sterility in sunflower (Helianthus annuus). Plant J. 1: 185-193. http://dx.doi.org/10.1111/ j.1365-313X.1991.00185.X

Lee J, Yoon JB and Park HG (2008). Linkage analysis between the partial restoration $(p r)$ and the restorer-of-fertility $(R f)$ loci in pepper cytoplasmic male sterility. Theor. Appl. Genet. 117: 383-389. http://dx.doi.org/10.1007/s00122-008$\underline{0782-7}$

Lee JS, Lee KH, Kim YS, Kang KK, et al. (2004). Detection of individuals restoring fertility by DNA fragment converted into STS (sequence tagged site) in red pepper. Plant Resour. 7: 136-140.

Ma Y, Huang W, Ji JJ, Gong ZH, et al. (2013). Maintaining and restoring cytoplasmic male sterility systems in pepper (Capsicum annuum L.). Genet. Mol. Res. 12: 2320-2331. http://dx.doi.org/10.4238/2013.January.4.8

Ma ZH, Yan SF, Luo XL, Shen XK, et al. (2001). Breeding and genetic analysis of yellow-green seedling mutant in pepper. J. Changjiang Veg. 4: 31-32.

Ma ZH, Hou XL, Song C and Shen XK (2005). Breeding of CMS lines with yellow bud mutant marker in chili pepper. $J$. China Capsicum 4: 19-23.

Ma ZH, Sun GS, Zhang CW, Wang Q, et al. (2016). Chlorophyll content, chloroplast ultrastructure and transcriptome analysis in wild-type and yellow-bud-mutant hot peppers. J. Agric. Sci. Technol.; JAST 18: 1065-1078.

Martin JA and Crawford JH (1951). Several types of sterility in Capsicum frutescens. Proc. Am. Soc. Hortic. Sci. 57: 335-338.

Monéger F, Smart CJ and Leaver CJ (1994). Nuclear restoration of cytoplasmic male sterility in sunflower is associated with the tissue-specific regulation of a novel mitochondrial gene. EMBO J. 13: 8-17.

Nivison HT and Hanson MR (1989). Identification of a mitochondrial protein associated with cytoplasmic male sterility in petunia. Plant Cell 1: 1121-1130. http://dx.doi.org/10.1105/tpc.1.11.1121

Novak F, Betlach J and Dubovsky J (1971). Cytoplasmic male sterility in sweet pepper (Capsicum annuum L.). I. Phenotype and inheritance of male sterile character. Z. Pflanzenzücht. 65: 129-140.

Peterson PA (1958). Cytoplasmically inherited male sterility in Capsicum. Am. Nat. 92: 111-119. http://dx.doi. org $/ 10.1086 / 282017$

Pingitore M, Matthews B and Bottino PJ (1989). Analysis of the mitochondrial genome of Daucus carota with male sterile and male fertile cytoplasm. J. Hered. 80: 143-145.

Powling A (1982). Restriction endonuclease analysis of mitochondrial DNA from sugarbeet with normal and male-sterile cytoplasms. Heredity 49: 117-120. http://dx.doi.org/10.1038/hdy.1982.70

Shifriss C (1997). Male sterility in pepper (Capsicum annuum L.). Euphytica 93: 83-88. http://dx.doi. org/10.1023/A:1002947907046

Shifriss C and Guri A (1979). Variation in stability of cytoplasmic-gene male sterility in C. annuum L. J. Am. Soc. Hortic. Sci. 104: 94-96.

Wang D and Bosland WP (2006). The genes of Capsicum. HortScience 41: 1169-1187.

Genetics and Molecular Research 16 (1): gmr16019459 
Xiao SH, Zhang TZ and Pan JJ (1995). Inheritance of virescent mutants and their utilization in heterosis of upland cotton. J. Nanjing Agric. Univ. 18: 28-33.

Young EG and Hanson MR (1987). A fused mitochondrial gene associated with cytoplasmic male sterility is developmentally regulated. Cell 50: 41-49. http://dx.doi.org/10.1016/0092-8674(87)90660-X

Yuan M, Yang GS, Fu TD and Yan HY (2003). Studies on the ecotypical male sterile-fertile line of Brassica napus L. III. Sensitivity to temperature of 8-8112AB and its inheritance. Acta Agron. Sin. 29: 330-335.

Genetics and Molecular Research 16 (1): gmr16019459 